\title{
Selection of phytotoxin producing rhizobacteria
}

\author{
DANIEL D.C. CARVALHO ${ }^{1}$, DENILSON F. OLIVEIRA ${ }^{2}$, VICENTE P. CAMPOS ${ }^{1}$ and MOACIR PASQUAL ${ }^{3}$ \\ ${ }^{1}$ Departamento de Fitopatologia, Universidade Federal de Lavras, Caixa Postal 3037, 37200-000 Lavras, MG, Brasil \\ ${ }^{2}$ Departamento de Química, Universidade Federal de Lavras, Caixa Postal 3037, 37200-000 Lavras, MG, Brasil \\ ${ }^{3}$ Departamento de Agricultura, Universidade Federal de Lavras, Caixa Postal 3037, 37200-000 Lavras, MG, Brasil
}

Manuscript received on June 19, 2009; accepted for publication on December 22, 2010

\begin{abstract}
In order to select phytotoxin producing rhizobacteria to control weed plants, twenty five bacterial strains previously isolated from the rhizospheres of various plants were grown in a liquid medium and, after cell removal by centrifugation, the liquid phases were freeze-dried and the products were extracted with ethyl acetate/methanol. The extracts were concentrated to dryness under vacuum and dissolved in water and sucrose solution to be submitted to in vitro assays of lettuce (Lactuca sativa L.) seed germination and wheat (Triticum aestivum L.) coleoptile growth. Although most samples affected coleoptile growth, only those from four strains reduced lettuce seed germination. Two strains of Bacillus cereus, one strain of B. pumilus and one of Stenotrophomonas maltophilia were the most promising microorganisms for producing phytotoxin and, consequently, for the development of new weed control products.
\end{abstract}

Key words: Bacillus, Stenotrophomonas, weeds, lettuce, wheat.

\section{INTRODUCTION}

Although herbicides are essential to obtain the necessary food and fiber, their use increases production costs and causes contamination of humans and the environment with harmful substances (Paoletti and Pimentel 2000, Tu et al. 2006). Thus, less expensive and less toxic methodologies to control weed must be developed. To circumvent such a problem, the use of rhizobacteria appears as a promising alternative, since some of these microorganisms are able to suppress the growth of specific plant species (Kremer and Souissi 2001, Hoagland 2001). They can be used directly in soil as bioherbicides (Mazzola et al. 1995) or to produce active metabolites against weeds. An example is Serratia plymuthica (strain A153), which is able to produce haterumalide A. This substance presents potential to control weeds, including the annual herbaceous such as Stellaria media, Thlaspi arvense and Chenopodium album (Gerhardson et al. 2001).

Correspondence to: Denilson F. Oliveira

E-mail: denilson@dqi.ufla.br
Since phytotoxin production is one of the mechanisms by which rhizobacteria act against plants (Alstrom and Burns 1989, Loper and Schroth 1986), in a preliminary work crude metabolites from some rhizobacteria were submitted to an assay with lettuce seeds (Lactuca sativa L.) to select those potentially useful for the development of new products to control weeds (Carvalho et al. 2007). In order to continue this research, this paper presents the effect of crude metabolites produced by some rhizobacterial strains different from those used in the previous work on wheat coleoptiles (Triticum aestivum L.) and lettuce seeds, which are considered excellent phytotoxin detectors (Stonard and Miller-Wideman 1994).

\section{MATERIALS AND METHODS}

\section{Production of Rhizobacterial Metabolites}

Rhizobacteria used in this study are housed in the Department of Plant Pathology - Federal University of Lavras, state of Minas Gerais, Brazil. They were pre- 
viously isolated from plant roots by J.L. Coimbra, unpublished data, who identified the microorganisms by fatty acid methyl ester analyses, which were carried out as described elsewhere (Kloepper et al. 1992, ChavarriaCarvajal et al. 2001). They were grown on tryptic soy agar (TSA - Merck KgaA) for two days, at $28^{\circ} \mathrm{C}$, and transferred to $250 \mathrm{~mL}$ of tryptic soy broth (TSB - Isofar Indústria e Comércio de Produtos Químicos) by the use of a sterilized needle that was introduced into the colonies grown on TSA. After ten days at $28^{\circ} \mathrm{C}$, under constant stirring $(100 \mathrm{rpm})$, bacterial cells were removed by centrifugation $(10,000 \mathrm{~g})$ and $70 \mathrm{~mL}$ of each supernatant liquid were freeze-dried. To each resulting residue were added $14 \mathrm{~mL}$ of a methanol/ethyl acetate $(\mathrm{MeOH} / \mathrm{AcOEt} ; 1: 1)$ solution, and the mixture obtained was filtered through a piece of cotton. The filtrates were concentrated to dryness in a rotary evaporator and dissolved in distilled water $(70 \mathrm{~mL})$ prior to their submission to the lettuce seed germination assay.

To carry out the wheat coleoptile growth assay, each supernatant liquid ( $3 \mathrm{~mL})$ was freeze-dried and washed with $12 \mathrm{~mL}$ of the $\mathrm{MeOH} / \mathrm{AcOEt}$ solution. The resulting liquids were concentrated to dryness in a rotary evaporator and dissolved in $6 \mathrm{~mL}$ of an aqueous $2 \%(\mathrm{~g} / \mathrm{mL})$ sucrose solution buffered at $\mathrm{pH} 5.0$ with $\mathrm{K}_{2} \mathrm{HPO}_{4}(1.794 \mathrm{~g} / \mathrm{mL})$ and monohydrated citric acid $(1.019 \mathrm{~g} / \mathrm{mL})$ (Nitsch and Nitsch 1996).

\section{Lettuce Seed Assay}

Fifty lettuce seeds (cv. Salad Bowl) were disposed in a transparent plastic box (GERBOX-11.4 × $11.4 \mathrm{~cm}$ ) containing two sheets of germination paper $(10.5 \times$ $10.5 \mathrm{~cm}$ ) embedding an amount of sample to be evaluated that was equivalent to 2.5 times the paper weight. After incubation at $20^{\circ} \mathrm{C}$ under a $12 \mathrm{~h}$ photoperiod per day, for seven days, the following parameters were used to evaluate the experiment: non-germinated seeds and healthy seedlings (Brasil 2009). Distilled water and TSB extract, obtained as described for rhizobacterial supernatant liquids, were employed as negative controls. An aqueous solution of glyphosate at $17.14 \mathrm{mg} / \mathrm{L}$, which was prepared from Agrisato $480 \mathrm{CS}$, produced by Alkagro do Brasil Ltda, was used as positive control. The experiment was carried out with four replicates, in a randomized design.

\section{Wheat Coleoptile Assay}

Wheat seeds (var. BRS-49) were disposed on sterilized humid sand, without light incidence, for three days. The first $2 \mathrm{~mm}$ (apical part) of five etiolated seedlings were discarded and coleoptiles (the following $4 \mathrm{~mm}$ ) were placed into $2 \mathrm{~mL}$ solutions containing samples to be evaluated. TSB extract, obtained as described for rhizobacterial supernatant liquids, was dissolved in an aqueous $2 \%(\mathrm{~g} / \mathrm{mL})$ sucrose solution buffered at $\mathrm{pH} 5.0$ to be used as negative control. Aqueous solutions of 2,4-dichlorophenylacetic acid (2,4-D; Sigma Chemical, Saint Louis, MO, USA) at $1.5 \mathrm{mg} / \mathrm{L}$ and glyphosate at $7.968 \mathrm{~g} / \mathrm{L}$ (prepared from Agrisato $480 \mathrm{CS}$, produced by Alkagro do Brasil Ltda) were used as positive controls. After $20 \mathrm{~h}$ at $25 \pm 2{ }^{\circ} \mathrm{C}$, in darkness, the coleoptiles were disposed on a flat black surface and photographed with a digital camera. Images were amplified (3.28 times) and a ruler was employed to measure coleoptile length in the printed figure. Then, coleoptiles were freeze-dried and weighed. The experiment was carried out with three replicates, each one comprising five coleoptiles.

\section{Statistical AnAlysis}

Values of non-germinated seeds and healthy seedlings, proceeding from the lettuce assay, were directly submitted to analysis of variance, followed by comparison of means by Scott and Knott (1974) calculations ( $P \leq 0.05$ ). Regarding the wheat assay, length (fifteen coleoptiles) and dry mass of three replicates (each one comprising five coleoptiles) were, separately, transformed into percentages before calculations. Statistical analyses were done using SISVAR software (Ferreira 2008).

\section{RESULTS}

Only metabolites produced by the two strains of Bacillus cereus, Bacillus pumilus (strain 83-20) and Stenotrophomonas maltophilia (strain 56-21) presented phytotoxic effects in the lettuce seed germination assay (Table I). Except for the strains 83-01, 83-20, 54-11, 58-10 and 62-17, the length or mass of wheat coleoptiles was statistically smaller than the observed for TSB (after freeze-drying and extraction). Nevertheless, just 
TABLE I

Effect of rhizobacterial metabolites on the germination of lettuce seeds and growth of wheat coleoptiles.

\begin{tabular}{|c|c|c|c|c|c|}
\hline \multirow[b]{2}{*}{ Rhizobacteria and controls } & \multirow[b]{2}{*}{ Plant source } & \multicolumn{2}{|c|}{ Lettuce $^{\mathrm{a}}$} & \multicolumn{2}{|c|}{ Wheat coleoptile $^{\mathrm{a}}$} \\
\hline & & $\begin{array}{c}\text { Healthy } \\
\text { seedlings } b\end{array}$ & $\begin{array}{c}\text { Nongerminated } \\
\text { seeds }\end{array}$ & $\begin{array}{c}\text { Length } \\
(\%)\end{array}$ & $\begin{array}{c}\text { Mass } \\
(\%)\end{array}$ \\
\hline Water & & $45.2^{\mathrm{b}}$ & $4.0^{\mathrm{a}}$ & - & - \\
\hline Sucrose at $2 \%$ & & - & - & $91^{\mathrm{d}}$ & $102^{\mathrm{d}}$ \\
\hline Glyphosate $-01^{\mathrm{c}}$ & & $0.0^{\mathrm{a}}$ & $2.0^{\mathrm{a}}$ & - & - \\
\hline Glyphosate $-02^{\mathrm{d}}$ & & - & - & $56^{\mathrm{a}}$ & $53^{\mathrm{a}}$ \\
\hline $\mathrm{TSB}^{\mathrm{e}}$ & & $45.0^{\mathrm{b}}$ & $2.0^{\mathrm{a}}$ & $100^{\mathrm{e}}$ & $100^{\mathrm{d}}$ \\
\hline $2,4-D^{f}$ & & - & - & $109^{\mathrm{f}}$ & $130^{\mathrm{e}}$ \\
\hline $\begin{array}{l}\text { Bacillus cereus } \\
\text { Frankland and Frankland } \\
\text { (strain } 83-01 \text { ) }\end{array}$ & Zea mays L. & $0.0^{\mathrm{a}}$ & $2.2^{\mathrm{a}}$ & $110^{\mathrm{f}}$ & $96^{\mathrm{d}}$ \\
\hline B. cereus (strain 83-02) & Zea mays L. & $0.0^{\mathrm{a}}$ & $6.7^{\mathrm{a}}$ & $92^{\mathrm{d}}$ & $92^{\mathrm{c}}$ \\
\hline $\begin{array}{l}\text { Bacillus megaterium } \\
\text { de Bary (strain 54-12) }\end{array}$ & Coffea arabica $\mathrm{L}$. & $43.5^{\mathrm{b}}$ & $2.5^{\mathrm{a}}$ & $77^{\mathrm{b}}$ & $61^{\mathrm{a}}$ \\
\hline $\begin{array}{l}\text { Bacillus pumilus } \\
\text { Meyer and Gottheil } \\
\text { (strain 55-08) }\end{array}$ & Solanum lycopersicum L. & $43.7^{\mathrm{b}}$ & $3.2^{\mathrm{a}}$ & $97^{\mathrm{d}}$ & $99^{d}$ \\
\hline B. pumilus (strain 55-26) & Trapaeolum majus L. & $47.7^{\mathrm{c}}$ & $0.7^{\mathrm{a}}$ & $77^{\mathrm{b}}$ & $86^{\mathrm{c}}$ \\
\hline B. pumilus (strain 55-28) & Coffea arabica $\mathrm{L}$ & $48.5^{\mathrm{c}}$ & $1.0^{\mathrm{a}}$ & $90^{\mathrm{d}}$ & $97^{\mathrm{d}}$ \\
\hline B. pumilus (strain 56-28) & Solanum lycopersicum L. & $42.0^{\mathrm{b}}$ & $2.0^{\mathrm{a}}$ & $88^{\mathrm{c}}$ & $97^{\mathrm{d}}$ \\
\hline B. pumilus (strain 83-12) & Zea mays L. & $48.0^{\mathrm{c}}$ & $0.7^{\mathrm{a}}$ & $71^{b}$ & $52^{\mathrm{a}}$ \\
\hline B. pumilus (strain 83-13) & Zea mays L. & $47.0^{\mathrm{c}}$ & $1.7^{\mathrm{a}}$ & $85^{\mathrm{c}}$ & $76^{\mathrm{b}}$ \\
\hline B. pumilus (strain 83-14) & Solanum lycopersicum L. & $46.2^{\mathrm{c}}$ & $1.7^{\mathrm{a}}$ & $76^{\mathrm{b}}$ & $87^{\mathrm{c}}$ \\
\hline B. pumilus (strain 83-15) & Zea mays $\mathrm{L}$. & $46.5^{\mathrm{c}}$ & $2.2^{\mathrm{a}}$ & $87^{\mathrm{c}}$ & $91^{\mathrm{c}}$ \\
\hline B. pumilus (strain 83-20) & Solanum lycopersicum L. & $0^{\mathrm{a}}$ & $49.2^{\mathrm{c}}$ & $104^{\mathrm{e}}$ & $96^{\mathrm{d}}$ \\
\hline B. pumilus (strain 84-02) & Zea mays $\mathrm{L}$. & $46.2^{\mathrm{c}}$ & $1.2^{\mathrm{a}}$ & $93^{d}$ & $71^{\mathrm{b}}$ \\
\hline B. pumilus (strain 84-03) & Crotalaria sp. & $48.5^{\mathrm{c}}$ & $1.0^{\mathrm{a}}$ & $91^{\mathrm{d}}$ & $108^{\mathrm{d}}$ \\
\hline B. pumilus (strain 84-07) & Crotalaria sp. & $47.7^{\mathrm{c}}$ & $2.0^{\mathrm{a}}$ & $91^{\mathrm{d}}$ & $87^{\mathrm{c}}$ \\
\hline B. pumilus (strain $85-10$ ) & Solanum lycopersicum L. & $48.0^{\mathrm{c}}$ & $1.7^{\mathrm{a}}$ & $95^{\mathrm{d}}$ & $95^{\mathrm{d}}$ \\
\hline $\begin{array}{l}\text { Klebsiella pneumoniae } \\
\text { (Schroeter) Trevisan } \\
\text { (strain 58-15) }\end{array}$ & Solanum lycopersicum L. & $48.0^{\mathrm{c}}$ & $0.7^{\mathrm{a}}$ & $92^{\mathrm{d}}$ & $78^{\mathrm{b}}$ \\
\hline $\begin{array}{l}\text { Stenotrophomonas maltophilia } \\
\text { Palleroni and Bradbury } \\
\text { (strain 54-11) }\end{array}$ & Trapaeolum majus L. & $46.7^{\mathrm{c}}$ & $1.5^{\mathrm{a}}$ & $102^{\mathrm{e}}$ & $101^{\mathrm{d}}$ \\
\hline S. maltophilia (strain 56-14) & Ricinus communis L. & $46.2^{c}$ & $2.2^{\mathrm{a}}$ & $95^{\mathrm{d}}$ & $84^{\mathrm{c}}$ \\
\hline S. maltophilia (strain 56-03) & Coffea arabica $\mathrm{L}$. & $48.2^{\mathrm{c}}$ & $1.0^{\mathrm{a}}$ & $86^{\mathrm{c}}$ & $88^{\mathrm{c}}$ \\
\hline S. maltophilia (strain 57-09) & Ricinus communis L. & $47.2^{\mathrm{c}}$ & $1.7^{\mathrm{a}}$ & $91^{\mathrm{d}}$ & $73^{b}$ \\
\hline S. maltophilia (strain 58-10) & Solanum melongena L. & $43.2^{\mathrm{b}}$ & $6.2^{\mathrm{a}}$ & $107^{\mathrm{f}}$ & $64^{\mathrm{a}}$ \\
\hline S. maltophilia (strain 58-25) & Solanum lycopersicum L. & $47.0^{\mathrm{c}}$ & $2.2^{\mathrm{a}}$ & $85^{\mathrm{c}}$ & $73^{b}$ \\
\hline S. maltophilia (strain 62-17) & Solanum lycopersicum L. & $48.5^{\mathrm{c}}$ & $0.7^{\mathrm{a}}$ & $105^{\mathrm{f}}$ & $105^{\mathrm{d}}$ \\
\hline S. maltophilia (strain 56-21) & Phaseolus vulgaris L. & $2.0^{\mathrm{a}}$ & $18.2^{\mathrm{b}}$ & $88^{\mathrm{c}}$ & $63^{\mathrm{a}}$ \\
\hline Coefficient of variability & & $6.4 \%$ & $21.9 \%$ & $8.8 \%$ & $8.8 \%$ \\
\hline
\end{tabular}

${ }^{a}$ Values with the same letter in each column do not differ statistically according to Scott and Knott (1974) calculations $(P \leq 0.05)$;

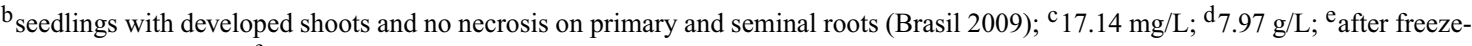
drying and extraction; ${ }^{\mathrm{f}} 1.5 \mathrm{mg} / \mathrm{L} ;(-)$ not evaluated. 
as verified for the auxin (2,4-D), one strain of Bacillus cereus (strain 83-01) and two of S. maltophilia (strains 62-17 and 58-10) caused increases in the wheat coleoptile length.

\section{DISCUSSION}

The toxic effects of B. cereus (strain 83-02) metabolites on lettuce seed germination and wheat coleoptile growth seemed reasonable (Table I), since in a previous work with another strain of this bacterium, isolated from Ricinus communis L., the corresponding metabolites affected lettuce seed germination and signalgrass (Brachiaria decumbens Stapf) seed germination to a great extent (Carvalho et al. 2007). According to the authors, metabolites from B. cereus (strain 57-02) caused necrosis on $82.6 \%$ of lettuce roots and afforded $48 \%$ of abnormal signalgrass seedlings (seeds exposed to water presented $20 \%$ of abnormal seedlings). Nevertheless, metabolites produced by strain 83-01 of $B$. cereus enhanced coleoptile length. Although these results may seem antagonistic to each other at a first glance, they are in accordance with the ability of $B$. cereus to produce indole-3-acetic acid (IAA), a plant growth promoter (Egamberdieva et al. 2008) that is toxic to plants when used at inhibitory concentrations, which should be above $10^{-4} \mathrm{M}$ to deleteriously affect oat coleoptile sections (Taiz and Zeiger 2006). Like IAA, the effects of other substances on plants are dose-dependent. An example is 2,4-dichlorophenylacetic acid (2,4D), which is commercially employed as a herbicide, but can be used as an auxin to promote plant growth in tissue cultures (Pasqual 2001). Particularly in this work, 2,4-D caused increases in both length and mass of coleoptiles (Table I).

Among the thirteen B. pumilus strains studied, only the one denominated 83-20 affected lettuce, preventing seed germination. A correlation with the plant from which the bacteria were isolated seemed improbable, since other strains isolated from the same plant species presented no effect on lettuce seed germination (Table I). Except for the strain 83-20, all the others reduced wheat coleoptile growth. Perhaps the apparent lack of relationship between these two assays can account for different concentrations of active substances in crude metabolites. Anyway, the activities detected seem in accordance with the reported use of $B$. pumilus as a bioherbicide (Japan Tobacco Inc. 1998).

S. maltophilia (strain 56-21) reduced the lettuce seed germination and wheat coleoptile growth (Table I), which is in accordance with the activity of such bacterium against the weed Bromus tectorum L. reported by Mazzola et al. (1995). Except for the strain 54-11, all the others (strains 56-14, 56-03, 57-09, 58-10, 58-25, 6217, and 56-21) affected wheat coleoptile growth, which in most cases was lower than the observed for those coleoptiles exposed to the control (TSB) (Table I). Probably this is a consequence of $S$. matophilia ability to produce IAA, the inhibiting or promoting effect of which, on plants, may be dose-dependent (Pasqual 2001).

Although Bacillus megaterium can present deleterious effect on weed growth (Kim and Kremer 2005) and on lettuce when combined with the fungus Glomus constrictum (Marulanda-Aguirre et al. 2008), lettuce seed germination was not affected by metabolites produced by such bacterium (Table I). However, the reduction of both length and mass occurred for wheat coleoptiles in contact with substances produced by $B$. megaterium. Similarly, K. pneumoniae metabolites presented no effect on lettuce seed germination, but reduced the wheat coleoptile length and mass. This result seems to be in accordance with the previously reported absence of phytotoxic effects on lettuce seeds by the metabolites of such bacterium (Carvalho et al. 2007).

Regardless of bacterial species used, the lack of relationship between the lettuce seed and the wheat coleoptile assays was easily observed, which may be partially due to the dose-dependent effects of some substances on plants (Pasqual 2001) and to the ability of some strains to produce more than one active substance (Karadeniz et al. 2006). An example is the production of the plant hormones IAA, giberelic acid, zeatin and abscisic acid by $B$. cereus grown in brain heart broth (Karadeniz et al. 2006). It is also possible that the absorption of active substances by plants have influenced the results, since a similar behavior can be observed for some commercial herbicides that are preferentially absorbed by leaves (Deuber 1992), which are more similar to coleoptiles than to seeds. Still worth mentioning is the difference among plants species used to carry out the assays that can result in various susceptibilities 
to the bacterial metabolites. Like the commercial herbicides sulfosate and glyphosate, perhaps the active substances produced by rhizobacteria presented increased toxicity to monocotiledons (Deuber 1992, Maciel et al. 2002). Future studies will be carried out under field and greenhouse conditions to evaluate the toxic effects of Bacillus cereus (strains 83-01 and 83-02), B. pumilus (strain 83-20) and Stenotrophomonas maltophilia (strain 56-21) on greenery crops and weeds.

\section{ACKNOWLEDGMENTS}

This work was supported by Fundação de Amparo à Pesquisa do Estado de Minas Gerais (FAPEMIG).

\section{RESUMO}

Com o objetivo de selecionar rizobactérias produtoras de fitotoxinas para uso no controle de plantas daninhas, vinte e cinco isolados bacterianos previamente obtidos das rizosferas de diferentes plantas foram cultivados em meio líquido e, após remoção das células por centrifugação, as fases líquidas foram liofilizadas e os resíduos obtidos foram submetidos à extração com acetato de etila/metanol. Os extratos foram concentrados sob vácuo até secura e dissolvidos em água e solução de sacarose para serem submetidos a testes in vitro de germinação de sementes de alface (Lactuca sativa L.) e de crescimento de coleóptilos de trigo (Triticum aestivum L.). Embora a maior parte das amostras tenha desfavorecido o crescimento dos coleóptilos de trigo, somente as provenientes de quatro isolados reduziram a germinação das sementes de alface. Dois isolados de Bacillus cereus, um isolado de B. pumilus e um de Stenotrophomonas maltophilia foram os microrganismos mais promissores para a produção de fitotoxinas, com possibilidade de uso no desenvolvimento de novos produtos para o controle de plantas daninhas.

Palavras-chave: Bacillus, Stenotrophomonas, plantas daninhas, alface, trigo.

\section{REFERENCES}

Alstrom S AND BURns RG. 1989. Cyanide production by rhizobacteria as possible mechanism of plant growth inhibition. Biol Fertil Soils 7: 232.

Brasil. 2009. Regras Para Análise de Sementes. Brasília: Ministério da Agricultura, Pecuária e Abastecimento. Secretaria de Defesa Agropecuária, 399 p.
CARVAlHo DDC, Oliveira DF, Corrêa RSB, CAMPos VP, Guimarães RM AND COIMBRA JL. 2007. Rhizobacteria able to produce phytotoxic metabolites. Braz $\mathrm{J}$ Microbiol 38: 759-765.

CHAVARria-CARVAJAL JA, RODRIGUEZ-KabANA R, Kloepper JW AND Morgan-Jones G. 2001. Changes in populations of microorganisms associated with organic amendments and benzaldehyde to control plant-parasitic nematodes. Nematropica 31: 165-180.

DEUBER R. 1992. Ciência das plantas daninhas: fundamentos. Jaboticabal: FUNEP, $431 \mathrm{p}$.

EgAmberdieVA D, KAMILOVA F, VALIDOV S, GAFUROVA L, Kucharova Z and Lugtenberg B. 2008. High incidence of plant growth-stimulating bacteria associated with the rhizosphere of wheat grown on salinated soil in Uzbekistan. Environ Microbiol 10: 1-9.

FERREIRA DF. 2008. SISVAR: um programa para análises e ensino de estatística. Rev Cient Symposium 6: 36-41.

Gerhardson B, Thaning C, WeIsSMann R, Borowicz J, Welch C AND Hedman R. 2001. New bacterial isolate and its active metabolites, including new compound Haterumalide X, useful for controlling weeds and treating fungal diseases in plants, human and animals. S.E. Pat. 9904334-A. Jul. 26.

HoAgland RE. 2001. Microbial allelochemicals and pathogens as bioherbicidal agents. Weed Technol 15: $835-857$.

JAPAN TOBACCO INC. 1998. Control composition for Echinochloa crus-galli - contains microorganisms of genus Bacillus that are herbicidally active on Echinochloa crus-galli. J.P. Pat. 10017424-A. Jan. 20.

Karadeniz A, Topcuoglu SF And InAN S. 2006. Auxin, gibberellin, cytokinin and abscisic acid production in some bacteria. WJ Microbiol Biotechnol 22: 1061-1064.

KIM SJ AND KREMER RJ. 2005. Scanning and transmission electron microscopy of root colonization of morningglory (Ipomoea spp.) seedlings by rhizobacteria. Symbiosis 39: 117-124.

Kloepper JW, RodrigueZ-Kabana R, McInroy JA AND YOUNG RW. 1992. Rhizosphere bacteria antagonistic to soybean cyst (Heterodera glycines) and rootknot (Meloidogyne incognita) nematodes-identification by fatty acid analysis and frequency of biological control activity. Plant Soil 139: 75-84.

KREMER RJ AND Souissi T. 2001. Cyanide production by rhizobacteria and potential for suppression of weed seedling growth. Current Microbiol 43: 182-186. 
LOPER JE AND SCHROTH MN. 1986. Influence of bacteria sources of indole-3-acetic acid on root elongation of sugarbeet. Phytopathology 76: 386-389.

Maciel CDG, Constantin J And Goto R. 2002. Seletividade e eficiência agronômica de herbicidas no controle de capim colchão na cultura da melancia. Hort Brasileira 20: 474-476.

Marulanda-Aguirre A, Azcon R, Ruiz-Lozano JM AND AROCA R. 2008. Differential effects of a Bacillus megaterium strain on Lactuca sativa plant growth depending on the origin of the arbuscular mycorrhizal fungus coinoculated: Physiologic and biochemical traits. J Plant Growth Regul 27: 10-18.

Mazzola M, Stahlman PW and Leach JE. 1995. Application method affects the distribution and efficacy of rhizobacteria suppressive of Downy Brome (Bromus tectorum). Soil Biol Biochem 27: 1271-1278.

Nitsch JP AND Nitsch C. 1996. Studies on the growth coleoptile and first internode sections. A new, sensitive, straight-growth test for auxins. Plant Physiology 31: 94-111.
Paoletti MG And Pimentel D. 2000. Environmental risks of pesticides versus genetic engineering for agricultural pest control. J Agr Environ Ethics 12: 279-303.

PASQual M. 2001. Meios de cultura, cultura de tecidos: tecnologia e aplicações. Lavras: Fundação de Apoio ao Ensino Pesquisa e Extensão, Universidade Federal de Lavras, $74 \mathrm{p}$.

ScotT AJ AND KnOtT M. 1974. Cluster analysis method for grouping means in the analysis of variance. Biometrics 30: 507-512.

Stonard RJ ANd Miller-Wideman MA. 1994. Herbicides and plant growth regulators. In: GODFREY CRA (Ed), Agrochemicals from Natural Products, New York: Marcel Dekker Inc., New York, USA, p. 215-255.

Taiz L And Zeiger E. 2006. Plant Physiology. 4. ed. Sunderland: Sinauer Associates, Inc. Publishers, 764 p.

Tu C, Ristaino JB And Hu S. 2006. Soil microbial biomass and activity in organic tomato farming systems: effects of organic inputs and straw mulching. Soil Biol Biochem 38: 247-255. 